\title{
İkinci Ürün Silajlık Mısırda Maksimum Net Geliri Sağlayan Sulama ve Azot Fertigasyon Stratejileri
}

\author{
Ramazan YOLCU' Neșe ÜZEN²* Öner ÇETIN² \\ 'Devlet Su İșleri 10. Bölge Müdürlüğü, Diyarbakır \\ ${ }^{2}$ Dicle Üniversitesi Ziraat Fakültesi Tarımsal Yapılar ve Sulama Bölümü, Diyarbakır
}

\author{
*Sorumlu yazar e-posta (Corresponding author e-mail) : nuzen@dicle.edu.tr \\ Geliș tarihi (Received) : 22.07.2016 \\ Kabul tarihi (Accepted): 19.09.2016
}

\section{Öz}

Bu çalıșmada, ikinci ürün silajık mısırda, farklı sulama ve azot fertigasyonu uygulamalarının birim alanda ve birim sulama suyundaki net gelire sulama suyu üretkenliği) etkisini araștırmak amaçlanmıștır. Araștırma, 2011 ve 2012 yıllarında Diyarbakır ilinde yapılmıștır. Deneme tesadüf bloklarında bölünmüș parseller deneme deseninde yürütülmüștür. Denemede, ana konuları 5 günlük açık su yüzeyi buharlașmasından elde edilen buharlașma miktarına göre farklı sulama suyu düzeyleri $\left(l_{1}: 0,50,1_{2}: 0,75,1_{3}: 1,00\right.$ ve $\left.I_{4}: 1,25\right)$; alt konuları ise fertigasyonda azotlu gübrenin farklı uygulama sıklı̆ı ( $\mathrm{N}_{1}$ :azotlu gübrenin \% 20'si ekimde, \% 40' । bitki 6-7 yapraklı olduğu dönemde diğer \%40'ı ise tepe püskülü döneminden önce; $\mathrm{N}_{2}$ : azotlu gübrenin \% 20'si ekimde, \% 80'i her iki sulamada (10 günde bir) bir eșit dozda tepe püskülü dönemine kadar; $N_{3}$ :azotlu gübrenin \% 20'si ekimde \% 80'i her sulamada (5 günde bir) eșit dozda tepe püskülü dönemine kadar) olușturmuștur. Sonuçlara göre, her iki yılda da uygulanan sulama suyu ve azot fertigasyon sıklığı arttıkça verim de artmıștır. Optimum koșullara göre, pan buharlașmasının 1,0 katı olan sulama suyunun $(447 \mathrm{~mm}$ ) her 5 günde bir uygulanması önerilmiș ve bu uygulamada silajlık yeșil ot verimi 87,9 t ha-1 olmuștur. Bu sonuçlara göre, en uygun veya maksimum sulama suyu kullanım etkinliği (SSKE) veya sulama suyu üretkenliği $19,6 \mathrm{~kg} \mathrm{da}^{-1} \mathrm{~m}^{-3}$, birim alandan elde edilen net gelir 305,4 TL da-1 ve birim hacim sulama suyuna karșllk elde edilen net gelir ise 1,78 $\mathrm{TL} \mathrm{m}^{-3}$ olarak elde edilmiștir.

Anahtar Kelimeler: Damla sulama, fertigasyon, net gelir, silajlık mısır, su üretkenliği

\section{Irrigation and Nitrogen Fertigation Strategies Providing the Maximum Net Return and Water Productivity for Second Crop Silage Corn}

\footnotetext{
Abstract

The objective of this study was to evaluate the effects of nitrogen fertigation and irrigation regimes of silage corn on net return and water productivity. The experiment was carried out using grown second crop silage corn in Diyarbakır from 2011 to 2012. The experimental design used split-plots in randomized blocks with three replications. The main plots contained four different rates of irrigation water (IN) and Class A pan evaporation (CPE); $\mathrm{I}_{1}: 0.50, \mathrm{I}_{2}: 0.75, \mathrm{I}_{3}: 1.00$ and $\mathrm{I}_{4}: 1.25$. In subplots; $\mathrm{N}_{1}$ : Application of twofifths of the total $\mathrm{N}$ when the plant height became about 6-7 leaves and the last two-fifths of it when the plants entered the stage of tasseling; $\mathrm{N}_{2}$ : Application of $\mathrm{N}$ applied at each two irrigation cycles for 10 days,
} 
and $\mathrm{N}_{3}$ : Application of $\mathrm{N}$ applied at each irrigation cycle for 5 day. One-fifth of the total $\mathrm{N}$ was applied to the soil at sowing in all treatment regimens. Increasing amount of water applied and fertigation frequency significantly increased fresh yield of silage corn in both two experimental years. According to the optimum conditions, the most appropriate irrigation scheduling and nitrogen fertigation were application of irrigation water (447 mm) consisting of $100 \%$ cumulative evaporation from Class A pan (Ep) and equal amounts of nitrogen at each irrigation cycle (5 days). For this treatment, the fresh silage corn yield was $87.9 \mathrm{t} \mathrm{ha}^{-1}$. The maximum water productivity or irrigation water use efficiency, net return per unit area and net return per volumetric water were $19.6 \mathrm{~kg} \mathrm{da}^{-1} \mathrm{~m}^{-3}, 305.4 \mathrm{TL} \mathrm{da}^{-1}$ and $1.78 \mathrm{TL} \mathrm{m}^{-3}$, respectively.

Key Words: Drip irrigation, fertigation, net return, silage corn, water productivity

\section{Giriș}

Ülkemiz hayvancılığının en önemli sorunu, hayvan varlığımızın yüksek olmasına karșılık kaliteli kaba yem açı̆̆ımızın fazla olmasıdır. Kaba yemler, çiftlik hayvanlarına taze olarak, kurutulmuș ve silaj yapılarak yedirilen bitkisel materyallerdir (Bahtiyarca ve Cufadar, 2003). Ülkemiz hayvanlarının kaliteli silaj yem intiyacını karșılamada silaj yapımının önemi büyüktür. Süt ineklerinin kuru madde tüketimlerinin en az \% 40’ kaba yemlerden sağlanmalıdır (Orak ve İptaș, 1999).

Son yıllarda, GAP bölgesinde iklimin de uygun olması nedeniyle ikinci ürün dane ve silajlık mısır yetiștiriciliği artmaya bașlamıștır. GAP Bölgesi'nde ikinci ürün mısır sulama suyu gereksinimi yüzey sulama için (800-1000 mm) oldukça yüksektir (Çetin, 1996). Yetiștiricilikte damla sulama sistemi gibi su ve enerji tasarrufu sağlayan modern teknolojilerin kullanılması ile mevcut su kaynaklarının optimum kullanımı sağlanabilir. Aynı bölgede Yazar vd., (2002) ile Öktem vd., (2002) misırda damla sulamanın verim üzerindeki etkilerini araștırmıșlar ve damla sulama kullanmanın önemli sulama suyu tasarrufu sağladığını belirtmișlerdir. Bu nedenle, su kaynaklarının daha etkin kullanılması, aynı zamanda gübrenin su ile birlikte verilmesine (fertigasyon) olanak sağlayan yeni sulama tekniklerinden olan damla sulama sistemlerinin tarım alanlarında özendirilmesi gerekmektedir (Yazar vd., 2002).

Fertigasyon, bitki besin maddelerinin etkin kullanımı, gübrelerin çevresel olumsuz etkisinin azaltılması, zaman ve iș gücü tasarrufu gibi temel avantajlar sağlayabilmektedir (Cetin ve Tolay, 2009). Öte yandan, fertigasyon yöntemi ile gübreler farklı zaman ve konsantrasyonda uygulanabilmektedir. Bunlar, sulama suyundaki besin elementi konsantrasyonları zamana bağı olarak konsantrasyonun azaltıması, sulama süresince sabit konsantrasyon, sulamanın yalnız bir bölümünde gübrenin tamamının uygulanması veya sulama süresince aralıklı ve eșit dozlar halinde uygulama șeklinde olabilir. Ayrıca bitkinin gelișim dönemleri ve azot kullanım miktarları da göz önüne alınarak fertigasyonda sulama süresince farklı oran ve miktarlar uygulanabilir (Manor vd., 1983).

Tarımda azotlu gübre kullanımı sulama ile birlikte en önemli girdilerden birisidir. Randall ve Schmitt (1993), azot uygulama zamanının önemli derecede azot kullanım etkinliğini etkileyebildiğini ve bu durumun yüzey sularında nitrat kirliliği için de bir etken olduğunu bildirmișlerdir. Keeny (1986), azot kayıplarını azaltmak için azotlu gübrenin bölünerek uygulanmasını önermiștir. Sencar (1988), mısırda yaptığı araștırmada, azot miktarı arttıkça, parselde koçan sayısı, koçanda tane verimi, protein oranı ve protein verimi artarken tepe püskülü ve koçan çıkarma süresinin kısaldığını, tane veriminin artan azot miktarına bağlı olarak artıș gösterdiğini, 21 ve $28 \mathrm{~kg} \mathrm{~N} \mathrm{da}^{-1}$ uygulamaları arasında fark olmadığını saptamıștır. Wuest ve Cassman (1992), ekim öncesinde uygulanacak fazla miktardaki N'un bir bölümünün vejetasyon ortalarına kaydırılarak geç uygulanması N kullanım etkinliğini ve tane protein içeriğini artırdığını belirtmiștir.

Bu çalıșma, Güneydoğu Anadolu Bölgesi Diyarbakır koșullarında 2011-2012 yıllarında ikinci ürün olarak yetiștirilen silajlık mısır bitkisinde yapıımıștır. Bu araștırmada, damla sulama ile farklı sulama suyu düzeylerinin ve fertigasyon sıklığının (azotlu gübre) silaj verimi ile birlikte birim alan ve birim su hacmine göre net gelir yönünden karșılaștırılması yapılmıștır.

\section{MATERYAL VE YÖNTEM}

Araștırma Diyarbakır ilinde DSi 10. Bölge Müdürlüğü Devegeçidi Baraj sahası içinde yer alan tarım arazisinde 2011-2012 yıllarında yapılmıștır. Deneme yeri toprakları düz, toprak bünyesi killi olup, tuzluluk ve taban suyu gibi herhangi bir sorunu 
bulunmamaktadır. İklim olarak, yazları oldukça kurak (bitki yetișme süresince genel olarak yağıș olmamaktadır) ve oldukça sıcaktır.

Araștırmada, C-955 (Dekalb) silajık mısır çeșidi kullanılmıștır. Bitkiler her iki deneme yılında da ikinci ürün olarak 25 Haziran'da ekilmiș olup, 2011 yılında 25 Eylül'de, 2012 yılında ise 20 Eylül'de hasat yapılmıștır. Denemede damla sulama sistemi kullanılarak, her iki sıraya tek lateral kullanıımıștır. Laterallerde damlatıcı aralığı 0,4 m ve damlatıcı debisi ise $4 \mathrm{~L} \mathrm{~h}^{-1}$ dir. Gübrelemede fertigasyon tekniği kullanıımıș olup, basınç farklılığı esasına göre çalıșan gübre tankı kanalıyla gübreler sulama suyu ile birlikte deneme konularına göre uygulanmıștır (Çetin ve Tolay, 2009).

Deneme, tesadüf bloklarında bölünmüș parseller deneme desenine göre 3 tekrarlamalı olarak yürütülmüștür. Ana parseller Class A pan buharlașmasından elde edilen değerlerin farklı oranlarını sulama suyu miktarları, alt parselleri ise azotlu gübre uygulamasında farklı fertigasyon sıklığı olușturmuștur (Çizelge 1). Her deneme parseli 4,2 $\mathrm{m} \times 8,0 \mathrm{~m}$ boyutlarında toplam 33,6 $\mathrm{m}^{2}$ lik alana sahip olup, her deneme parselinde 6 bitki sırası yer almıștır. Her iki mısır bitkisi sırasına bir lateral hattı döșenmiștir. Denemede bitki sıra aralığı 0,7 m, sıra üzeri ise $0,2 \mathrm{~m}^{\prime}$ dir. Parseller arasında $2,0 \mathrm{~m}$, bloklar arasında 3,0 m boșluk bırakılmıștır. Sulama aralığı 5 gün olarak uygulanmıștır.

Araștırmada deneme konularına, dekara saf olarak $10 \mathrm{~kg}$ Potasyum $\left(\mathrm{K}_{2} \mathrm{O}\right), 10 \mathrm{~kg}$ Fosfor $\left(\mathrm{P}_{2} \mathrm{O}_{5}\right)$ ve $24 \mathrm{~kg}$ Azot (N) gübresi uygulanmıștır (Kara vd., 1999; ibrikçi vd., 2001). Denemede taban gübresi olarak granüle 15-15-15, fertigasyonla (sulama ile birlikte gübrenin verilmesi) uygulanan gübre ise, katı toz forumunda 19-5-5 gübresi kullanıımıștır. Sulama suyu așağıda verilen Eșitlik 1 yardımıyla hesaplanmıștır (Cetin ve Bilgel, 2002).

$I=A \times E P \times K \times P$

Eșitlik' de;

I: Parsele uygulanacak sulama suyu (L),

A:Parsel alanı $\left(\mathrm{m}^{2}\right)$,

Ep: Sulama aralığındaki birikimli Class A Pan buharlașma miktarı (mm),

K: Deneme gereği esas alınan katsayısı

P: Islatma alanı oranı (Deneme gereği parsel alanının tamamı ıslatımadığından dolayı, ıslatma alanı oranı 0,65 sabit alınmıștır).

Yaș bitki parsel verimlerini tespit etmek üzere, hasat zamanı parseldeki tüm bitkiler toprak yüzeyinden kesilerek parçalanmıș ve tartımıștır. Projede ele alınan deneme konuları dikkate alındığında farklı uygulamalar arasında sulama suyu miktarı, fertigasyon sıklığı ve bunların ișçilik maliyetleri vb. bakımından bir farklılık olacağından, uygulamalar arasındaki net gelir kısmi bütçeleme yöntemi ile ortaya konmuștur (Olson, 2011). Net gelirin hesaplanmasında, toprak ișleme ve ekim, bakım ișleri, hasat-harman, çeșitli giderler ve ortak giderler (sermaye faizi, yönetim giderleri v.b.) esas alınarak, her konudaki sulama suyu miktarı, gübre ve su ücreti bașta olmak üzere o yılın silajık mısır için tüm değișken ve sabit girdi maliyetleri birim alan (da) üzerinden bölge koșulları için tespit edilmiștir. Buna göre, her uygulama için elde edilen verim üzerinden değerlendirme yapılmıștır (Koral ve Altun, 2000).

Sulama suyu kullanım etkinliği, kullanılan bitkiye bağlı olarak elde edilen toplam biomass veya tane veriminin kullanılan sulama suyuna oranı olarak hesaplanmıștır. Birim alandan elde edilen net gelir,

Çizelge 1. Deneme konuları

Table 1. Experimental treatments

\begin{tabular}{|c|c|}
\hline Ana konular & Alt konular \\
\hline Sulama suyu düzeyleri & Fertigasyonda azot gübresi uygulama sıklığı \\
\hline $\begin{array}{l}\text { I }_{1(0.50)} \text { : A sınıfı buharlașma } \\
\text { kabından olan buharlașan } \\
\text { miktarın } 0,50 \text { katı }\left(E_{0} \times 0,5\right)\end{array}$ & $\begin{array}{l}\mathrm{N}_{1} \text { : Azot gübresinin 1/5'i ekim ile birlikte, 2/5'i bitki boyu 6-7 yapraklı } \\
\text { olduğunda, diğer 2/5'lik kısmı ise tepe püskülü döneminde uygulanması }\end{array}$ \\
\hline$I_{2(0.75)}: E_{p} \times 0,75$ & $\begin{array}{l}N_{2} \text { : Azotlu gübrenin 1/5'i ekim ile birlikte, kalan 4/5'i ise her iki sulamada bir } \\
\text { (10 günde bir) eșit dozlarda, tepe püskülü dönemine kadar uygulanması }\end{array}$ \\
\hline$I_{3(1.00)}: E_{p} \times 1,0$ & $\begin{array}{l}\mathrm{N}_{3} \text { : Azotlu gübrenin 1/5'i ekim ile birlikte, kalan 4/5'i ise her sulamada (5 } \\
\text { günde bir) eșit dozlarda, tepe püskülü dönemine kadar uygulanması }\end{array}$ \\
\hline 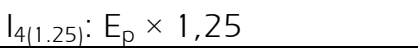 & \\
\hline
\end{tabular}


elde edilen net gelirin birim alana oranı olarak tanımlanmıș ve hesaplanmıștır. Birim sulama suyuna karșllık elde edilen net gelir ise birim alandan elde edilen net gelirin aynı alana uygulanan toplam sulama suyu miktarına veya hacmine oranı olarak tanımlanmıș ve hesaplanmıștır Buna göre sulama suyu kullanım etkinliği, birim alandan elde edilen net gelir ve birim sulama suyundan elde edilen net gelir așağıda verilen Eșitlik 2, 3 ve 4 yardımı ile hesaplanmıștır (Sinclair vd., 1984; Kijne vd., 2003; Sharma vd., 2015).

SSKE $=\frac{V}{S S}$

$N G A=\frac{N G}{S A}$

$N G S=\frac{N G}{S S}$

Yukarıdaki eșitliklerde; SSKE; sulama suyu kullanım etkinliğini $\left(\mathrm{kg} \mathrm{da}^{-1} \mathrm{~m}^{-3}\right), \mathrm{V}$; verimi $\left(\mathrm{kg} \mathrm{da}^{-1}\right)$, SS; sulama suyunu $\left(\mathrm{m}^{3} \mathrm{da}^{-1}\right)$, NGA; birim alandan elde edilen net geliri (TL da' ${ }^{-1}$ ), NG; net geliri (TL), SA; sulanan alanı (da), NGS; birim sudan elde edilen net geliri $\left(\mathrm{TL} \mathrm{m}^{-3}\right)$ göstermektedir.

Böylece, yukarıda verilen her bir deneme konusu için uygulanan farklı sulama suyuna karșilık birim alandan elde edilen gerçek verim (üretim) değeri kullanılarak, sulama suyu kullanım etkinliği, bașka bir ifade ile sulama suyu üretkenliği ile birim alandan ve birim sulama suyundan elde edilen net gelir hesaplanmıștır. Net gelir hesaplamalarında, her uygulamalarında ve her bölgenin kendi koșullarına göre gerçek ve güncel üretim masrafları ve ürün satıș fiyatları kullanılmıș olup ürün desteklemeleri de gelire dahil edilmiștir.

\section{BULGULAR VE TARTIȘMA}

\section{Silajlık Mısır Verimi}

Denemenin her iki yllında da (2011 ve 2012) sulama suyu miktarı ve $\mathrm{N}$ fertigasyon sıklığı arttıkça, silajlık yaș ot verimi istatistiksel olarak \% 1 hata düzeyinde etkilenmiștir (Çizelge 2). Uygulamalar arasında interaksiyon olmadığı için, konu verimleri ayrı ayrı değerlendirmiștir. Genel olarak sulama suyu miktarı arttıkça silaj verimi de artmıștır (Schmaler vd., 2003; Bouazzama vd., 2012). Yapılan Duncan çoklu karșılaștırma grupları da Çizelge 2'de gösterilmiștir. Sulama suyu açısından, her ne kadar en yüksek yeșil ot verimleri pan buharlașmasının 1,25 katı uygulamasından $\left(I_{4}\right)$ elde edilse de, optimum verim için pan buharlașmasının 1,0 katı uygulaması göz önüne alınabilir. Benzer șekilde, Oktem vd., (2003) mısır için, pan buharlașmasının \% 100'ünün uygulandığı sulama programının uygun olduğunu bildirmiștir.

$\mathrm{N}$ fertigasyon uygulama sıklığı arttıkça yeșil ot verimi de artmıștır. Buna göre en yüksek verim her sulamada 15 günde bir) azotlu gübrenin uygulamasından $\left(\mathrm{N}_{3}\right)$ elde edilmiștir. Uygulanan sulama suyu ise konu bazında 285-529 mm arasında değișmiștir (Çizelge 3).

Optimum verim ve sulama suyu tasarrufu göz önüne alındığında pan buharlașma miktarının 1,0 katı uygulaması sonucu ortalama $447 \mathrm{~mm}$ (447 $\mathrm{m}^{3} \mathrm{da}^{-1}$ ) sulama suyu uygulaması ikinci ürün silajlık mısır yetiștiriciliği için yeterli olduğu sonucuna varılabilir.

\section{Sulama Suyu Kullanım Etkinliği (SSKE) (Sulama Suyu Fiziksel Üretkenliği)}

Sulama suyu kullanım etkinliği (SSKE), birim alana uygulanan sulama suyuna karșilık elde edilen verimin ifadesi olup, bu ise sulama suyu fiziksel üretkenliği olarak da adlandırılmaktadır (Kijne vd., 2003). Buna göre, SSKE değerleri 14,4$20,5 \mathrm{~kg} \mathrm{da}^{-1} \mathrm{~m}^{-3}$ arasında değișmiștir (Çizelge 3). Daha az sulama suyu miktarlarının uygulandığı konularda SSKE daha yüksek elde edilmiștir (Kang ve Zhang, 2004). Bu bulgulara benzer șekilde, Yazar vd. (2002) ile Rusere vd., (2012) eksik sulamada verimin önemli düzeyde azaldığını buna karșın ise SSKE'nin ise arttığını tespit etmișlerdir. Maksimum verimin elde edildiği $I_{4} N_{3}$ ve $I_{3} N_{3}$ konularında sırasıyla, SSKE 16,9 ve $19,6 \mathrm{~kg} \mathrm{da}^{-1}$ $\mathrm{m}^{-3}$ olmuștur.

Çizelge 2. Yıllara göre elde edilen yeșil ot verimleri (t da- ${ }^{1}$ )

Table 2. The fresh silage corn yield according to the experimental years (t $\left.d \mathrm{a}^{-1}\right)$

\begin{tabular}{lccccc}
\hline Sulama suyu düzeyi & 2011 & 2012 & N Fertigasyon sıklığı & 2011 & 2012 \\
\hline $\mathrm{I}_{1(0.50)}$ & $5,58 \mathrm{c}$ & $5,81 \mathrm{c}$ & $\mathrm{N}_{1}$ & $6,43 \mathrm{~b}$ & $6,74 \mathrm{c}$ \\
$\mathrm{I}_{2(0.75)}$ & $6,58 \mathrm{~b}$ & $6,89 \mathrm{bc}$ & $\mathrm{N}_{2}$ & $6,77 \mathrm{~b}$ & $7,28 \mathrm{~b}$ \\
$\mathrm{I}_{3(1.00)}$ & $7,45 \mathrm{a}$ & $7,95 \mathrm{ab}$ & $\mathrm{N}_{3}$ & $7,48 \mathrm{a}$ & $7,90 \mathrm{a}$ \\
$\mathrm{I}_{4(1.25)}$ & $7,98 \mathrm{a}$ & $8,59 \mathrm{a}$ & & & \\
\hline
\end{tabular}


Çizelge 3. Deneme konularının silajlık mısır verimi ve net gelir üzerine etkisi (Veriler iki yılın ortalamasıdır)

Table 3. Effects of experimental treatments on silage corn yield and net return ( The average of two years of data)

\begin{tabular}{|c|c|c|c|c|c|}
\hline $\begin{array}{l}\text { Deneme } \\
\text { konuları }\end{array}$ & $\begin{array}{l}\text { Sulama suyu } \\
\mathrm{m}^{3} \mathrm{da}^{-1}\end{array}$ & $\begin{array}{l}\text { Yeșil ot verimi } \\
\mathrm{kg} \mathrm{da}^{-1}\end{array}$ & $\begin{array}{c}\text { IWUE } \\
\mathrm{kg} \mathrm{da}^{-1} \mathrm{~m}^{-3}\end{array}$ & $\begin{array}{c}\text { Net gelir } \\
\text { (birim alana göre) } \\
T_{\text {TL da }}^{-1} \\
\end{array}$ & $\begin{array}{c}\text { Net gelir } \\
\text { (birim su hacmine göre) } \\
\mathrm{TL} \mathrm{m}^{-3}\end{array}$ \\
\hline $\mathrm{I}_{1} \mathrm{~N}_{1}$ & 285 & 5393 & 18,9 & $-36,5$ & $-0,33$ \\
\hline${ }_{1} N_{2}$ & 285 & 5844 & 20,5 & 13,8 & 0,13 \\
\hline${ }_{1} N_{3}$ & 285 & 5856 & 20,5 & 15,2 & 0,14 \\
\hline $\mathrm{I}_{2} \mathrm{~N}_{1}$ & 366 & 6405 & 17,5 & 58,3 & 0,41 \\
\hline $\mathrm{I}_{2} \mathrm{~N}_{2}$ & 366 & 6615 & 18,1 & 81,8 & 0,58 \\
\hline $\mathrm{I}_{2} \mathrm{~N}_{3}$ & 366 & 7178 & 19,6 & 144,6 & 1,03 \\
\hline $\mathrm{I}_{3} \mathrm{~N}_{1}$ & 447 & 6935 & 15,5 & 99,4 & 0,58 \\
\hline${ }_{3} N_{2}$ & 447 & 7382 & 16,5 & 149,2 & 0,87 \\
\hline$I_{3} N_{3}$ & 447 & 8782 & 19,6 & 305,4 & 1,78 \\
\hline $\mathrm{I}_{4} \mathrm{~N}_{1}$ & 529 & 7617 & 14,4 & 157,2 & 0,77 \\
\hline${ }_{1} \mathrm{~N}_{2}$ & 529 & 8282 & 15,7 & 231,3 & 1,14 \\
\hline $\mathrm{I}_{4} \mathrm{~N}_{3}$ & 529 & 8960 & 16,9 & 307,0 & 1,51 \\
\hline
\end{tabular}

Ancak, SSKE bu deneme sonucunda da olduğu gibi, her zaman maksimum ve/veya optimum verimin elde edildiğinin bir göstergesi olmayabilir. Buna göre diğer göstergeler olan birim alandan elde edilen net gelir ve/veya birim sulama suyuna karșilık elde edilen net gelir durumuna göre değerlendirmek daha doğrudur.

\section{Birim Alana Göre Net Gelir}

Net gelir hesabında kullanılan üretim maliyetleri, silajlık mısır yetiștiriciliği için tüm üretim girdileri (tohum maliyetleri, çapa, tarım ilaçları, gübre, hasat, nakliye, arazi ișleme vb.) dikkate alınarak hesaplanmıștır (Kuscu vd., 2013). Böylece, mevsimsel üretim maliyetleri tüm uygulamalar için sulama suyu miktarı ve gübreleme için ișgücü dıșında birim alan için aynı bitki yoğunluğu olduğu için aynıdır.

Farklı N-fertigasyon sıklığı ve sulama suyu miktarının silajlık mısırda birim alandan elde edilen net gelir Çizelge 3 'de gösterilmiștir. Birim alandan elde edilen net gelir incelendiğinde Pan buharlașma miktarının 1,0 katı uygulaması olan $\mathrm{I}_{3} \mathrm{~N}_{3}$ konusundan $\left(305,4 \mathrm{TL} \mathrm{da}^{-1}\right)$ ve Pan buharlașma miktarının 1,25 katı olan $\mathrm{I}_{4} \mathrm{~N}_{3}$ konusundan 1307,0 $T L d a^{-1}$ ) en yüksek net gelirler elde edildiği tespit edilmiștir. Bununla birlikte $I_{4} N_{3}$ ile $I_{3} N_{3}$ uygulaması arasında çok küçük bir fark olmasına rağmen, kullanılan sulama suyu miktarı göz önüne alındığında, dolayısıyla sulama suyu tasarrufu da esas alınırsa, net gelir açısından $I_{3} N_{3}$ uygulaması önerilebilir (Çizelge 3).

\section{Birim Su Miktarına Göre Net Gelir}

Her sulama uygulamasında su maliyeti, mısır bitkisi için gerekli olan toplam sulama suyu miktarı ile birim hacim bașına sulama suyu fiyatının çarpılması ile bulunmuștur. Sulama suyu ve fertigasyon uygulama sıklığına karșılık toplam net gelirler Çizelge 3'de verilmiștir. Ekonomik analiz ve değerlendirme; her uygulama için kullanılan toplam sulama suyu, ișletme ve üretim maliyetleri ve toplam sulama süresi kullanılarak hesaplanmıștır. Ayrıca, sulama ișgücü maliyeti; sulama suyu miktarı ve sulama süresine bağlı olarak hesaplanmıștır. Çizelge 3'den de inceleneceği gibi, farklı sulama suyu miktarı ve fertigasyon uygulamalarına karșılık alınan en yüksek net gelir pan buharlașma miktarının 1,0 katı uygulaması ve fertigasyon uygulama sıklığının 5 gün olduğu olan $I_{3} N_{3}$ konusundan $\left(1,78 \mathrm{TL} \mathrm{m}^{-3}\right)$ elde edilmiștir. Sulama suyu miktarı ve $\mathrm{N}$ fertigasyon uygulama sıklığının artması silajık mısırda yeșil ot verimini de arttırmıștır. Buna bağlı olarak da net gelir de artmıștır (Çizelge 3).

\section{SONUÇLAR}

Bu araștırma sonucuna göre, uygulanan sulama suyu düzeyleri ve konular arasındaki farklar esas alındığında, toprak ve su kaynaklarının sürdürülebilirliği ile optimum bir ișletmecilik için silajlık mısır yetiștiriciliğinde, pan kabından olan buharlașma miktarının 1,0 katı kadar sulama suyunun (toplam $447 \mathrm{~mm}$ veya $447 \mathrm{~m}^{3} \mathrm{da}^{-1}$ ) 5 günde bir verilmesi uygun bulunmuștur. Buna göre, 
fertigasyonla azotlu gübrenin her 5 günde bir pan kabından olan toplam buharlașma miktarının 1,0 katı alınması ve uygun ıslatma alanı oranı veya örtü yüzdesi ile de düzeltilerek uygulanması önerilebilir. Bu sonuçlara göre, en uygun veya maksimum sulama suyu kullanım etkinliği (SSKE) $19,6 \mathrm{~kg} \mathrm{da}^{-1}$ $\mathrm{m}^{-3}$, birim alandan elde edilen net gelir 305,4 TL da' ' ve birim sulama suyuna karșllık elde edilen net gelir ise 1,78 TL m³ olarak elde edilmiștir.

\section{KAYNAKLAR}

Bahtiyarca Y, Çufadar Y (2003). Konya ili yem bitkileri üretimi, Ulusal I. Konya Ekonomisi Sempozyumu, 401-409, 1718 Nisan, Konya.

Bouazzama B, Xanthoulis D, Bouaziz A, Ruelle P, Mailhol J $C$ (2012). Effect of water stress on growth, water consumption and yield of silage maize under flood irrigation in a semiarid climate of Tadla (Morocco). Biotechnologie, Agronomie, Société et Environment, 16 (4), 468-477.

Çetin Ö (1996). Harran ovası koșullarında ikinci ürün mısır su gereksinimi. K.H. Șanlıurfa Araștırma Enstitüsü Müdürlüğü Yayınları No: 90/63, Șanlıurfa.

Cetin O, Bilgel L (2002). Effects of different irrigation methods on shedding and yield of cotton. Agric. Water Manage. (54)1: 1-15.

Cetin Ö, Tolay I (2009). Fertigasyon: Sulama Ille Birlikte Gübreleme. HASAD Yayıncılık, ISBN: 978-975-8377-69-5, İstanbul, s. 160.

İbrikçi H, Ülger A C, Șen H M, Büyük G, Güzel N, Çakır B, Özgentürk G (2001). Çukurova bölgesinde ikinci ürün mısır yetiștiriciliğinde azotlu gübre kullanımının optimizasyonu. Tarp1951 nolu proje Kesin Sonuç Raporu. TÜBITAK

Kang S Z, Zhang J H (2004). Controlled alternate partial root-zone irrigation: its physiological consequences and impact on water use efficiency. J. Exp. Bot. 55, 2437-2446.

Kara Ș M, Deveci M, Özbay D, Șekeroğlu N (1999). Farklı bitki sıkığı ve azot dozlarının silaj mısırda yeșil ot verimi ve bazı özellikler üzerine etkileri. Türkiye 3. Tarla Bitkileri Kongresi. Cilt III. Çayır-Mera Yem Bitkileri ve Yemeklik Tane Baklagiller. 172177. 15-18 Kasım, Adana.

Keeny D (1986). Sources of nitrate to ground water. Crit. Rev. Environ. Control, 16: 257-304.

Kijne J, Barker R, Molden D (2003). Improving water productivity in agriculture: Editors' Overview, in Jacob Kijne and others (Eds.) Water Productivity in Agriculture: Limits and Opportunities for Improvement, Comprehensive Assessment of Water Management in Agriculture. UK: CABI Publishing in Association with International Water Management Institute.

Koral A i, Altun A (2000). Türkiye'de Üretilen Tarım Ürünlerinin Girdileri Rehberi. Köy Hizmetleri Gen. Müd. APK Dairesi Bașkanlığı, Toprak ve Su Kaynakları Șubesi, Yayın No: 104, Rehber No: 16, Ankara
Kuscu H, Karasu A, Oz M, Demır A O, Turgut I (2013). Effect of irrigation amounts applied with drip irrigation on maize evapotranspiratıon, yıeld, water use efficiency, and net return in a sub-humid climate. Turkish Journal of Field Crops. 18(1), 13-19.

Manor S, Lovvengart A, Brum M, Hazan A, Bar I, Geva S (1983). The technology of chemigation: uniformity of distribution in the irrigation. 3rd International Conference on Irrigation, 3-6 October, Tel-Aviv, Israel.

Olson K D (2011). Economics of Farm Management in a Global Setting. John Wiley and Sons, USA, 560 p.

Orak A, İptaș S (1999). Silo yem bitkileri ve silaj. Çayır mera amenajmanı ve ıslahı. Tarım ve Köyișleri Bakanlığı Tarımsal Üretim ve Geliștirme Genel Müdürlüğü. 49 -69. Ankara.

Öktem A, Șimșek M, Öktem A G (2002). Deficit irrigation effect on sweet corn (Zea Mays Saccharata Sturt) with drip irrigation system in a semi-arid region: i. water-yield relationship. Department Of Field Crops, Faculty Of Agriculture, Harran University, 63200, Șanliurfa, Turkey.

Öktem A, Simsek M, Öktem A G (2003). Deficit irrigation effects on sweet corn (Zea mays saccharata Sturt) with drip irrigation system in a semi-arid region: I. Water-yield relationship. Agric. Water Manage. 61 (1), 63-74.

Randall GW, Schmitt M A (1993). Best management practices for nitrogen use statewide in Minnesota. University of Minnesota Extension Service.

Rusere F, Soropa G, Svubure O, Gwatibaya S, Moyo D, Ndeketeya A, Mavima G A (2012). Effects of deficit irrigation on winter silage maize production in Zimbabwe. International Research Journal of Plant Science, Vol. 3(9) pp. 188-192.

Schmaler K, Kruger U, Richert H (2003). Ertrag und qualita"t von silomais in abha"ngigkeit vom wasserangebot. Arch Agron Soil Sci 49(4):357-374.

Sencar Ö (1988). Mısır yetiștiriciliğinde ekim sıklığı ve azotun etkileri. Cumhuriyet Üniv. Ziraat Fak. Yayınları 6. Tokat.

Sharma B, Molden D, Cook S (2015). Water use efficiency in agriculture: Measurement, current situation and trends. In: Managing Water and Fertilizer for Sustainable Agricultural Intensification (Editors: Drechsel, P., Heffer, P., Magen, H., Mikkelsen, R., Wichelns, D., Managing Water and Fertilizer for Sustainable Agricultural Intensification. International Fertilizer Industry Association (IFA), International Water Management Institute (IWMI), International Plant Nutrition Institute (IPNI), and International Potash Institute (IPI). First edition, Paris, France, ISBN 979-10-92366-02-0, pp. 39-64.

Sinclair T R, Tanner C B, Bennett J M (1984). Water-use efficiency in crop production. Bioscience, 34 (1), pp. 36-40.

Wuest S B, Cassman K G (1992). Fertilizer nitrogen use efficiency of irrigated wheat: ii. Portioning efficiency of preplant versus late-season application. Agron. J., 84:689-694.

Yazar A, Sezen S M, Gencel B, (2002). Drip irrigation of corn in the Southeast Anatolia Project (GAP) area in Turkey. Irrig. And Drainage. 51,293-300. 